\title{
Physicochemical Characterization of Moroccan Natural Clays and the Study of their Adsorption Capacity for the Methyl Orange and Methylene Blue Removal from Aqueous Solution
}

\author{
Meryem Assimeddine ${ }^{1}$, Mohamed Abdennouri ${ }^{1}$, Noureddine Barka ${ }^{1}$, Elhossein Rifi' ${ }^{2}$,'hamed \\ Sadiq ${ }^{1, *}$ \\ ${ }^{1}$ Sultan Moulay Slimane University of Beni Mellal, Research Group in Environmental Sciences and Applied Materials (SEMA), \\ FP Khouribga, B.P. 145, 25000 Khouribga, Morocco \\ ${ }^{2}$ Ibn Tofail University of Kenitra, Research Group in Organic Synthesis and Extraction Process, Faculty of Sciences, \\ University Campus, BP 133, Kenitra, Morocco
}

Received: 04/05/2020 Accepted: 24/8/2020 Published: 20/12/2020

\begin{abstract}
The objective of this work was the physicochemical characterization of a Moroccan natural clay from the Jorf Arfoud region (Lampert Coodinates: $\mathrm{x}=595610, \mathrm{y}=101578$ ) and its valorization in the elimination of organic pollutants (methyl orange MO and methylene blue $\mathrm{MB}$ ) from aqueous solutions, with the adsorption technique on raw and calcined clay at $500^{\circ} \mathrm{C}$. The clay was characterized by chemical analysis such as X-ray fluorescence (XRF), X-ray diffraction (XRD), Fourier Transform Infrared Spectroscopy (FTIR) and Scanning electron microscopy (SEM). Crude and purified clays, consisting essentially of silica and alumina, are a characteristic property of phyllosilicates and also contain amounts of quartz, kaolinite and calcite as associated minerals. The experiments were performed after optimization of the parameters influencing the system, such as $\mathrm{pH}$, adsorbent mass, initial dye concentration and temperature. The clays used absorb better the $\mathrm{MB}$ than MO, for an initial concentration of $10 \mathrm{mg} / \mathrm{L}$ and $20 \mathrm{mg} / \mathrm{L}$ respectively. Langmuir and Freundlich models of adsorption isotherms were applied to fit experimental equilibrium data. Results have showed that the adsorption of MB and MO followed very well the second order kinetic model on raw clay. The adsorption process was found to be exothermic in the case of MB. However, the adsorption of MO was endothermic.
\end{abstract}

Keywords: Natural Clay; Adsorption; isotherm and kinetic studies; Dye removal

\section{Introduction}

Water is the most important natural resource made available to the future of humanity. It is essential for existence of life and maintaining ecological balance of planet. Amongst the growing impact caused directly or indirectly by humans, science and technology development are made the environmental mess with a big pollution problem. Dyes industrials are one of the main pollutants. From recent years, the textile industry emissions are heavily loaded with most organic dyes. These are often used in excess to improve dyeing; hence discharge water is highly concentrated dyes whose low biodegradability makes their treatments difficult, which is a source of environmental degradation $[1,2]$.

Several authors used physical, chemical and biological methods to treat and discolor polluted effluents, such as coagulation and flocculation [3], biodegradation [4], membrane filtration [5], photodegradation and adsorption [6-8]. Removal of refractory organics and emerging contaminants from industrial effluents using the microbial electrochemical technologies is a sustainable proposition as discussed in review paper [9]. The adsorption technique is one of the more favorable method for the removal of dyes. It has become an analytical method of choice, very effective and easy to use [10].

This work focuses on the use of a locally available natural clay as adsorbent, low cost, biodegradable and made from natural sources [11]. The clays play an important role in some areas, such as the manufacture of therapeutic and cosmetic products [12-14] and treatment of wastewater, for example in adsorption of toxic organic compounds. It is a no polluting material that can be used as a depleting agent for wastewater and heavy metal laden water, due to its lofty adsorption capacity [15]. The adsorption and desorption process of organic dyes by clays are principally controlled by the surface property of the clay and the chemical properties of the molecules [16]. goethite blended natural

Corresponding author: M'hamed Sadiq, Sultan Moulay Slimane University of Beni Mellal, Research Group in Environmental Sciences and Applied Materials (SEMA), FP Khouribga, B.P. 145, 25000 Khouribga, Morocco. Tel: +212 666248196 ; Fax: +212 523490354 and E-mail: m.sadiq@usms.ma ; sadiqmhamed@hotmail.com 
clayware-based membranes have been previously reported as a low-cost alternative proton exchange membrane in microbial fuel cell application [17]. They showed that Natural clay-based membranes have significantly lower proton conductivity than Nafion 117 membrane. Microbial Fuel Cell-Membrane Bioreactor developed system by Bhowmick et al. [18] demonstrated the best treatment of medium-strength organic wastewater; Overall chemical oxygen demand (COD) and total Kjeldahl nitrogen (TKN) removal efficiency of around $98 \%$ and $82 \%$ were achieved from the combined process, respectively. In one other work of Bhowmick et al. [19], Conductive ink printed $\mathrm{Co}_{3} \mathrm{O}_{4}$ and $\mathrm{Fe}_{3} \mathrm{O}_{4}$ were used as cathode catalyst, which demonstrated an improved electrical performance and wastewater treatment efficacy of microbial fuel cell.

The purpose of this study was to test the capacity of Moroccan natural clay as a low-cost adsorbent for the removal of methyl orange and methylene blue from aqueous solution to replace the current expensive methods of waste water. The effect of deferent parameter such as the adsorbent dose, $\mathrm{pH}$, initial concentration of dye and temperature were studied.

\section{Materials and methods \\ 2.1 Materials}

All the reagents chemicals used in the study were of analytical grade. Methylene blue and methyl orange ware provided by the Sigma-Aldrich chemicals and used without further purification. The chemical formula and some physicochemical properties of these dyes are summarized in table 1. Methylene blue is a cationic dye. It causes in man, in case of ingestion, an increase in heart rate, vomiting, quadriplegia, and tissue necrosis [20]. Methyl range is an anionic dye soluble in water, widely used in the chemical, textile and paper industries. It is an anionic dye that poses a serious risk to the environment [21-23].

\subsection{Sampling}

The clay samples used in this study were mineralogical mixtures dominated by Silica and Alumina. The chemical composition of the clay sample was determined by X-ray fluorescence. The results are given in table 2. The clay was sampled, air-dried, and then crushed, calcined at $500^{\circ} \mathrm{C}$, in a tubular furnace for 4 hours.

\subsection{Characterization techniques}

Adsorbent diffractograms were recorded at room temperature using a D2 PHASER powder diffractometer, equipped with a copper anticathode $\left(\mathrm{CuK}_{\alpha}\right.$ line, $\left.\lambda=1,5406 \AA\right)$ operated at $30 \mathrm{kV}$ and $10 \mathrm{~mA}$. Bragg-geometry-Brentano has been employed. The samples were irradiated in a $2 \theta$ angular range from $5^{\circ}$ to $80^{\circ}$, with a $0.01^{\circ}$ measurement pitch and a $0.5 \mathrm{sec} / \mathrm{step}$ count time. Infrared spectroscopy measurements were obtained using a Fourier transform spectrometer, type Perkin Elmer (FTIR-2000). The samples are packaged as pellets, consisting of $1 \mathrm{mg}$ of the test substance, diluted in $100 \mathrm{mg} \mathrm{KBr}$. The results are presented in absorbance for wavenumbers between 4000 and $400 \mathrm{~cm}^{-1}$. We used a scanning electron microscope JEOL JSM 6400. This device has an acceleration voltage of up to $40 \mathrm{kV}$, the images are usually made at $20 \mathrm{kV}$. Chemical analysis by X-ray fluorescence makes it possible to determine precisely the overall chemical composition of a solid sample. The device used is a wavelength dispersion spectrometer-Type Axios and the method of preparation is pastille (PROT -ELE03-v01).

\subsection{Adsorption kinetics \\ 2.4.1 Pseudo-first-order model}

This model assumes that the sorption rate at the moment ' $\mathrm{t}$ ' is proportional to the difference between the amount adsorbed at equilibrium $\left(\mathrm{q}_{\mathrm{e}}\right)$, and the amount adsorbed at the moment ' $\mathrm{t}$ ' $\left(\mathrm{q}_{\mathrm{t}}\right)$, and that the adsorption is reversible [24]. The equation of the law of speed is written:

$\frac{d q}{d t}=k_{1}\left(q_{e}-q_{t}\right)$

where; $\mathrm{q}_{\mathrm{t}}$ and $\mathrm{q}_{\mathrm{e}}$ are the adsorption capacities at time $\mathrm{t}$ and equilibrium respectively, in $(\mathrm{mg} / \mathrm{g}), \mathrm{k}_{1}$ is the pseudo-first order velocity constant $\left(\mathrm{min}^{-1}\right)$ and $\mathrm{t}$ is the contact time (min).

The integration of equation (1) gives:

$q=q_{e}\left(1-e^{-k_{1} t}\right)$

Table 1: Physicochemical characteristics of used dyes

$\begin{array}{cccc}\text { Name } & \text { Nature } & \mathrm{MW}_{\mathrm{max}}(\mathrm{g} / \mathrm{mm}) \\ \text { Methylene blue } \\ \text { (Basic blue 9) }\end{array}$




\subsubsection{Pseudo-second-order model}

The adsorption kinetics can be described by the pseudosecond order model. The differential equation is generally known and described as [25]:

$\frac{d q_{t}}{d t}=k_{2}\left(q_{e}-q_{t}\right)^{2}$

The integration of equation (3) gives:

$q_{t}=\frac{k_{2} q_{e}^{2} t}{1+k_{2} q_{e} t}$

where $\mathrm{k}_{2}(\mathrm{~g} / \mathrm{mg}$. $\mathrm{min})$ is the rate constant of pseudo-second order adsorption.

\subsection{Adsorption isotherms}

The relationship between the quantity fixed of adsorbate and the equilibrium solution concentration have been described by theoretical or empirical models proposed by several authors. These are non kinetic relationships, called isotherms. In general, such isotherms are processed by several models, including Langmuir, Dubinin-Radushkevich, Freundlich, Temkin, Elovich, BET etc....

The Freundlich and Langmuir isotherms are the most commonly used models in the literature.

\subsubsection{Langmuir isotherm}

The adsorption model of Langmuir [26] is based on the following assumptions: uniform energetic adsorption sites, single-ply coverage, and no lateral interaction between adsorbed molecules. Graphically, a tray characterizes the isotherm of Langmuir. Therefore, at equilibrium, a saturation point is reached where no further adsorption can occur. A theoretical expression of the Langmuir isotherm is given by the following equation:

$$
q_{e}=\frac{q_{m} K_{L} C_{e}}{1+K_{L} C_{e}}
$$

The value of $\mathrm{K}_{\mathrm{L}}$ is related to the interaction force between the adsorbed molecule and the surface of the solid, the value of $\mathrm{q}_{\mathrm{m}}$ expresses the quantity of solute fixed per gram of solid the surface of which is considered to be totally covered by a monomolecular layer [27].

\subsubsection{Freundlich isotherm}

In this model, the number of sites likely to adsorb the compound is unlimited. Thus, the Freundlich isotherm has no maximum unlike that of Langmuir. This empirical model is widely used for the practical representation of adsorption equilibrium. Freundlich isotherm can be given as follows [28]:

$q_{e}=K C_{e}^{1 / n}$

$\mathrm{q}_{\mathrm{e}}$ is amount adsorbed per gram of solid, $\mathrm{C}_{\mathrm{e}}$ is concentration of adsorbent at adsorption equilibrium, $\mathrm{K}$ and $\mathrm{n}$ being two constants where $\mathrm{K}$ is a parameter essentially related to the maximum capacity, and $\mathrm{n}$ is a parameter related to coefficients of variation of the energies interacting with the overlap rate [29]. The shape of obtained isotherms may suggest the interfacial interaction type between the adsorbent and the adsorbate. Giles [30] classified the isotherms into four types: Linear type $\mathrm{C}(1 / \mathrm{n}=1)$, Convex type $\mathrm{S}$ $(1 / \mathrm{n}>1)$, Concave type $\mathrm{L}(1 / \mathrm{n}<1)$ and type $\mathrm{H}(1 / \mathrm{n}<<1)$.

\subsection{Adsorption studies}

The required initial dye concentrations were prepared by dissolving the desired weight of each dye in distilled water. The sorption processes were carried out in a series of $200 \mathrm{~mL}$ beakers containing the desired clay weight and $200 \mathrm{~mL}$ of the colouring solution at a given concentration. These experiments were carried out with constant agitation by varying the clay mass from 1 to 4 $\mathrm{g} / \mathrm{L}$, the contact time from 0 to $360 \mathrm{~min}$, the $\mathrm{pH}$ of the solution, the initial dye concentration from 10 to $50 \mathrm{mg} / \mathrm{L}$ and the temperature from 10,30 and $50^{\circ} \mathrm{C}$. The $\mathrm{pH}$ of the solution was adjusted by adding $\mathrm{NaOH}(0.1 \mathrm{~N})$ or $\mathrm{HCl}(0.1 \mathrm{~N})$ and using a sensION ${ }^{+} \mathrm{pH}$ meter. Temperature was controlled using a Cryothermostat. After each adsorption test, the solid phase was separated from the liquid phase by syringe filters, and the concentration was determined from its UV-Vis absorbance characteristic with the calibration curve method at the maximum absorption wavelength at $461 \mathrm{~nm}$ for methyl orange and $661 \mathrm{~nm}$ for methylene blue. A TOMOS V-1100 UV-Vis spectrophotometer was used. The adsorption capacity was calculated using the following equations:

$q=\frac{\left(C_{0}-C\right)}{R}$

and the removal efficiency (\%) can be calculated as follows:

$\%$ Removal $=\frac{\left(C_{0}-C\right)}{C_{0}} \times 100$

Where $\mathrm{q}$ is the adsorbed quantity $(\mathrm{mg} / \mathrm{g}), \mathrm{C}_{0}$ is the initial dye concentration $(\mathrm{mg} / \mathrm{L}), \mathrm{C}$ is the dye concentration at a time $\mathrm{t}$ $(\mathrm{mg} / \mathrm{L})$ and $\mathrm{R}$ is the mass adsorbents per liter of solution $(\mathrm{g} / \mathrm{L})$.

\section{Results and discussions 3.1 Characterization \\ 3.1.1 Chemical analysis by X-ray fluorescence}

The analytical results obtained by X-ray fluorescence are grouped in table 2 . It can be seen from these values that the percentage of silica and alumina is very high, indicating the presence of Kaolinite $\left(\mathrm{Al}_{2} \mathrm{Si}_{2} \mathrm{O}_{5}(\mathrm{OH})_{4}\right)$. As well as for calcium which is relatively high, so this material is rich in calcite $\left(\mathrm{CaCO}_{3}\right)$. The Alumina/Silica ratio provides information on the permeability of the material vis-à-vis moisture, the greater this ratio the greater the permeability [31]. In our case, this ratio is small $\mathrm{Al}_{2} \mathrm{O}_{3} / \mathrm{SiO}_{2}=0.38$ for both samples; this low value indicates the low percentage of moisture. The overall composition of the other oxides $\left(\mathrm{Fe}_{2} \mathrm{O}_{3}, \mathrm{MgO}\right.$ and $\left.\mathrm{K}_{2} \mathrm{O}\right)$ reaches a percentage of 8.353 for the raw clay not calcined and of 9.987 for the calcined which shows that our clays are not pure [32]. After the treatment thermic, an increase of composition of clay is observed, due mainly to the loss of physically adsorbed water and departure of structural $\mathrm{OH}$ from Kaolinite (confirmed by XRD).

\subsubsection{X-ray diffraction}

The mineralogical composition evolution of the raw and calcined clay sample is illustrated by figure 1 . X-ray diffraction analysis indicates that the both samples have almost the same composition. They are composed of Quartz $\left(\mathrm{SiO}_{2}\right)$, Calcite $\left(\mathrm{Ca}\left(\mathrm{CO}_{3}\right)\right)$, and reveal the presence of a weak line that can be 
attributed to the Illite $\left(\left(\mathrm{NH}_{4}, \mathrm{~K}\right)(\mathrm{Si}, \mathrm{Al})_{4} \mathrm{Al}_{2} \mathrm{O}_{10}(\mathrm{OH})_{2}\right)$ and Montmorillonite $\left(\left(\mathrm{Na}_{0.3}(\mathrm{Al}, \mathrm{Mg})_{2} \mathrm{Si}_{4} \mathrm{O}_{10}(\mathrm{OH})_{2} .8 \mathrm{H}_{2} \mathrm{O}\right)\right.$ phases, with the presence of the Kaolinite phase $\left(\mathrm{Al}_{2} \mathrm{Si}_{2} \mathrm{O}_{5}(\mathrm{OH})_{4}\right)$ in the raw clay not calcined. This later phase decomposes under effect of calcination at $500^{\circ} \mathrm{C}$. The diffractograms show the presence of a more intense peak, corresponding to the Quartz. The clay fraction of our materials consists of Quartz and Calcite as a major compound in our samples, this confirms the results of Fluorescence $\mathrm{X}$ which show high proportions of $\mathrm{SiO}_{2}$ (Quartz).

Table 2: Mineralogical composition of clays

\begin{tabular}{lcc}
\hline Composition & \% Raw clay & \% Calcined clay in $500^{\circ} \mathrm{C}$ \\
\hline $\mathrm{SiO}_{2}$ & 30,552 & 36,741 \\
$\mathrm{Al}_{2} \mathrm{O}_{3}$ & 11,846 & 14,254 \\
$\mathrm{CaO}$ & 9,409 & 10,574 \\
$\mathrm{Fe}_{2} \mathrm{O}_{3}$ & 4,878 & 5,929 \\
$\mathrm{~K}_{2} \mathrm{O}$ & 2,294 & 2,682 \\
$\mathrm{MgO}$ & 1,181 & 1,376 \\
$\mathrm{TiO}_{2}$ & 0,769 & 0,905 \\
$\mathrm{SO}_{3}$ & 0,231 & 0,799 \\
$\mathrm{P}_{2} \mathrm{O}_{5}$ & 0,405 & $* *$ \\
\hline
\end{tabular}

\subsubsection{FTIR spectroscopy}

The IR spectra of raw and calcined clays (figure 2) show the different characteristic absorption bands of clays recorded between 4000 and $400 \mathrm{~cm}^{-1}$. For both clay samples (raw and calcined), we observe a broad absorption band around $3650 \mathrm{~cm}^{-1}$ characterizing the $\mathrm{O}-\mathrm{H}$ bond, indicating the presence of water and
$\mathrm{OH}$ units in their mineral structure [33]. A band centered at 1450 $\mathrm{cm}^{-1}$ is attributed to the $v_{3}\left(\mathrm{CO}_{3}\right)^{2-}$ antisymmetric stretching mode of carbonate, where as the band at $880 \mathrm{~cm}^{-1}$ is assigned to the binding vibration of carbonate $v_{2}$. These bands confirm the presence of calcium carbonate $\mathrm{CaCO}_{3}$ [34]. Langford et al. [35] show that the peaks from 900 to $1150 \mathrm{~cm}^{-1}$ could be the characteristic bending of $\mathrm{Al}-\mathrm{OH}$ and stretching of Si-O vibrations of weathered sheet silicates, principally illite and kaolinite. However, an intense and wide absorption band centered at 1052 $\mathrm{cm}^{-1}$ characterizes the valence vibrations of the Si-O bond [36] The doublet peak observed at 802 and $799 \mathrm{~cm}^{-1}$ are attributable to the $\mathrm{Si}-\mathrm{O}$ link elongation vibrations of quartz mineral, where as the peak at $695 \mathrm{~cm}^{-1}$ is assigned to the $\mathrm{Si}-\mathrm{O}$ perpendicular vibration of silicates minerals [35]. The vibration bands of the Si-O-M $\mathrm{MI}^{\mathrm{VI}}$ bonds ( $\mathrm{M}$ denotes the $\mathrm{Al}, \mathrm{Mg}$ and $\mathrm{Fe}$ metals located in the octahedral position) appear in 538 and $486 \mathrm{~cm}^{-1}$. Therefore, the absorption bands found by infrared confirm the results obtained by X-ray diffraction.

\subsubsection{Scanning electron microscope SEM}

The surface morphology of the raw and calcined clays was observed by scanning electron microscope SEM. This technique makes it possible to highlight the "macroporosity" character of the samples. The resulting images are shown in figure 3 . The morphologies observed by scanning electron microscope of the different phases are in the form of clusters of fine aggregates with irregular contours. On the other hand, the morphology of the natural clay not calcined is more compact than that of the calcined, this is explained by the efficiency of the calcination by allowing to increase the specific surface of the clay by pores creation. In addition, we observe that the interparticular pores of uncalculated clay are smaller than those in calcined clay.

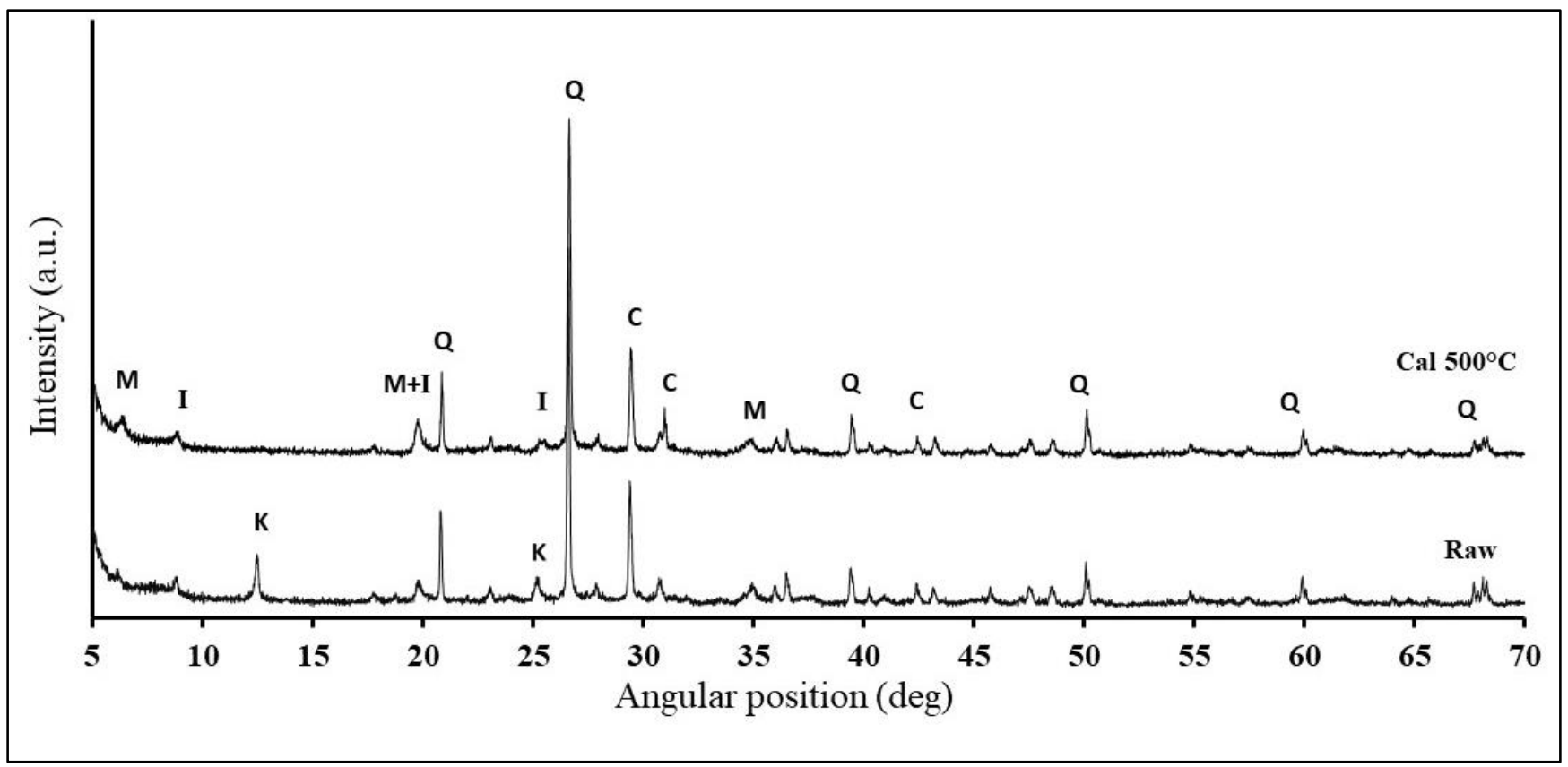

Figure 1: Clay diffractograms: Quartz (Q), Calcite (C), Illite (I), Montmorillonite (M) and Kaolinite (K) 


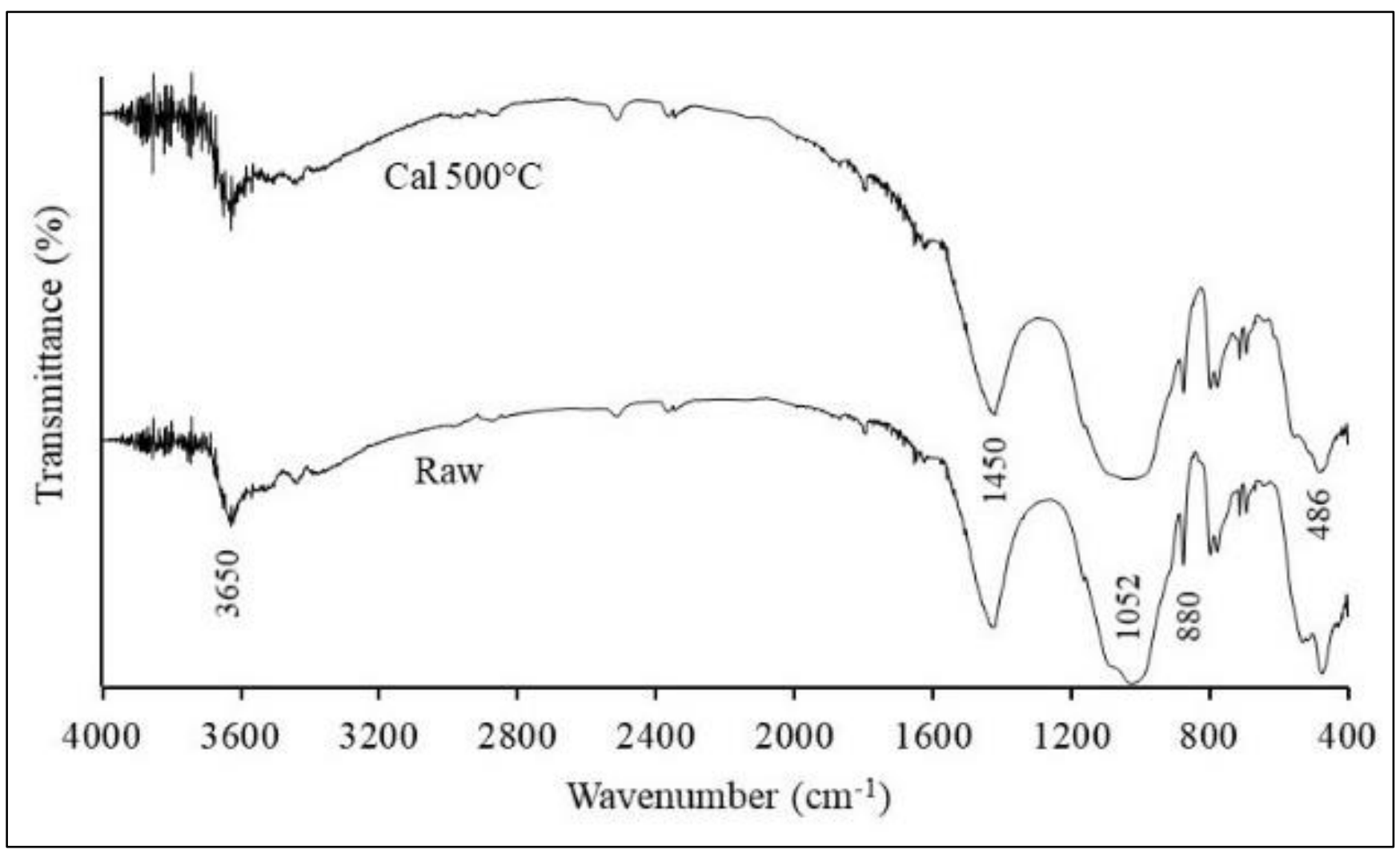

Figure 2: FT-IR spectra of raw and calcined clays
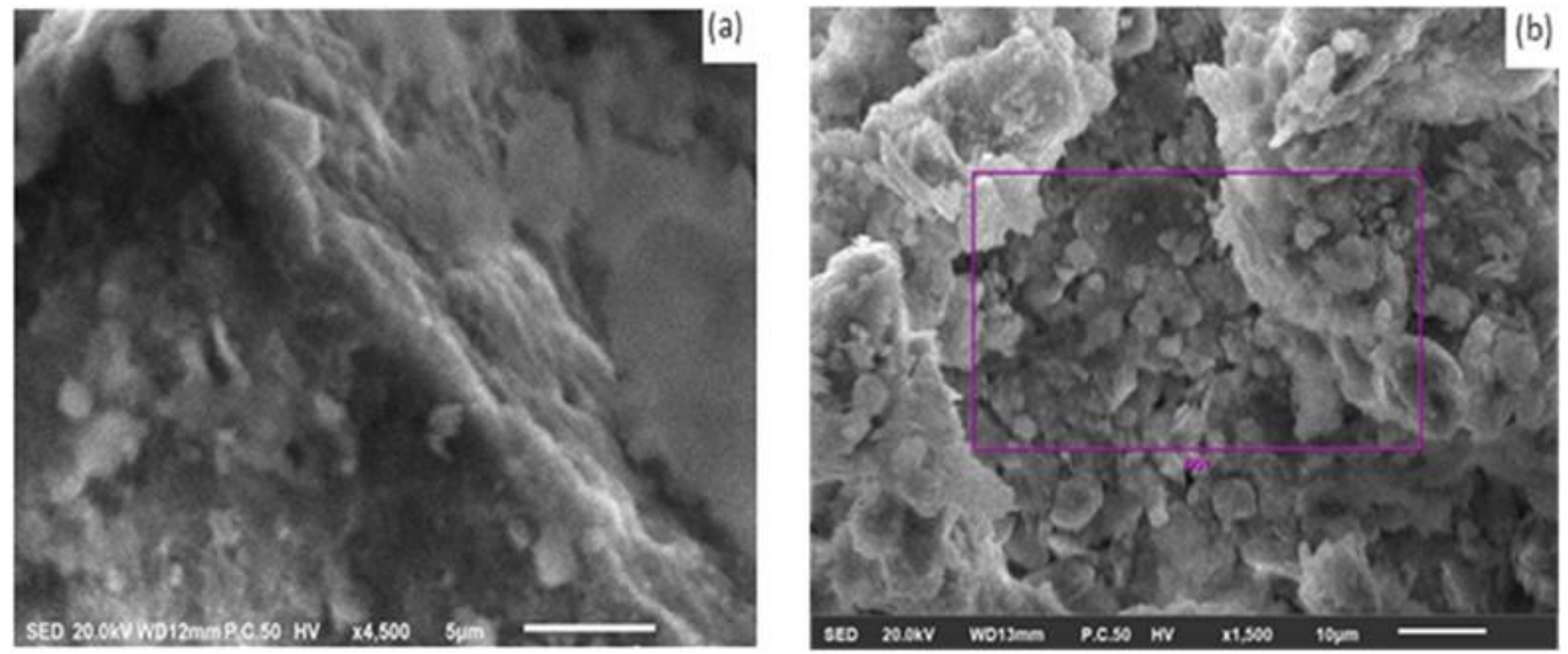

Figure 3: SEM image of raw clay (a) and SEM image of calcined clay (b)

\subsection{Adsorption study \\ 3.2.1 Adsorbent mass}

Figures 4 and 5 represent, respectively, the variation in the amounts adsorbed by clay to MB and MO and the percentage of removal. The curves show that the quantities retained are maximum for the low ratios and decrease with the increase in this ratio. This variation is due to an increase in the free surface area of clay grains for low ratios.
On the basis of the results obtained from the adsorption of methylene blue, we note that the adsorption capacity of the raw clay is almost the same as that of the calcined clay. The maximum adsorption capacity is recorded for gross with $98 \%$ removal and $96 \%$ for the other with a mass of $1 \mathrm{~g}$ per liter of solution. the residual concentration of $\mathrm{MB}$ in the solution was $0,17 \mathrm{mg} / \mathrm{L}$ and $0,4 \mathrm{mg} / \mathrm{L}$ after the adsorption over the raw and calcined clay, respectively. the optimum value of the residual concentration $(0,07 \mathrm{mg} / \mathrm{L})$ was obtained after $180 \mathrm{~min}$ of adsorption of $\mathrm{MB}$ on 
$1 \mathrm{~g} / \mathrm{L}$ of raw clay, this corresponds to $99,4 \%$ optimum removal of MB.

For the adsorption of orange methyl, the adsorption capacity is very low compared to methylene blue. This result can be interpreted by the anionic nature of $\mathrm{MO}$, and the cationic nature of BM which gives it a great affinity with the clays. Both types of clay give almost the same results with a removal percentage equal to $8 \%$ with a mass of $4 \mathrm{~g}$ per liter of solution. in this case, the final concentration of $\mathrm{MO}$ in the solution was $18 \mathrm{mg} / \mathrm{L}$ for both supports raw and calcined clay.

\subsection{2 $\mathrm{pH}$ effect on methyl orange adsorption}

We have limited ourselves only to the study of MO just to improve the percentage of elimination, because in the case of $\mathrm{MB}$ the percentage is reached $99 \%$ without modifying the working conditions. Figure 6 shows the influence of $\mathrm{pH}$ variation on the adsorption of methyl orange (MO) on uncalcined raw clay.

In our study, for the MO dye, there is a low adsorbability regardless of the $\mathrm{pH}$ value (acid or basic), this is due to the anionic nature of the MO which in its anionic form is repelled by the clay surface due to the electrostatic effects (electrostatic repulsion phenomenon).

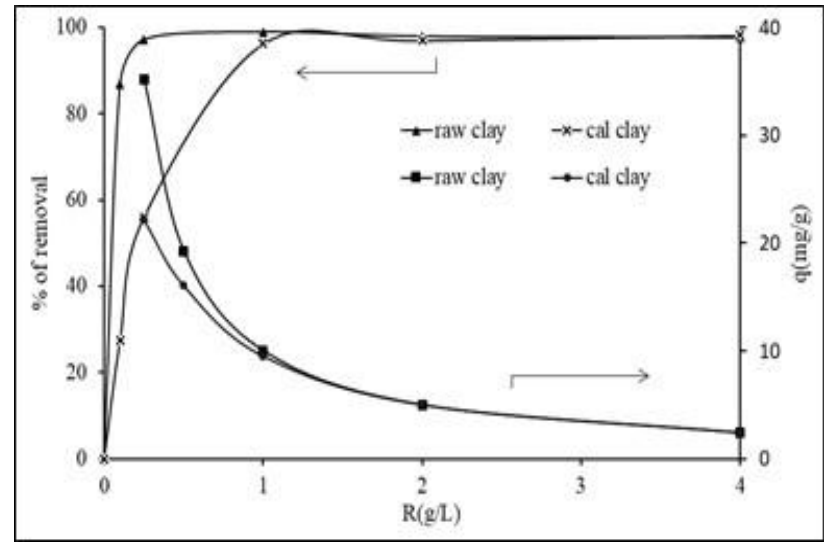

Figure 4: Effect of adsorbent mass on MB adsorption. $\mathrm{C}_{0}=10 \mathrm{mg} / \mathrm{L}$ Contact time $=180 \mathrm{~min}, \mathrm{RT}$

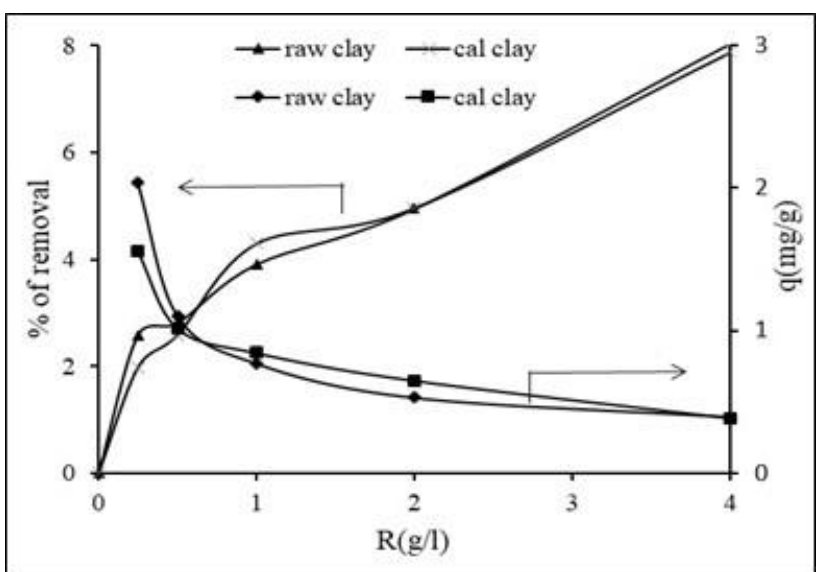

Figure 5: Effect of adsorbent mass on MO adsorption. $\mathrm{C}_{0}=20 \mathrm{mg} / \mathrm{L}$, Contact time $=180 \mathrm{~min}, \mathrm{RT}$

\subsubsection{Effect of initial MB dye concentration}

Figure 7 shows the evolution of the adsorbed amount of BM dye per gram of raw clay as a function of contact time at different initial $\left(20,30,40,50 \mathrm{mg} \mathrm{L}^{-1}\right)$ dye concentrations. The recorded curves show that the amount of adsorbate fixed on the material increases with the increase in the content of the methylene blue solution. In fact, the increase in concentration induces an increase in the driving force of the concentration gradient, thus increasing the diffusion of dye molecules in solution through the adsorbent surface [37].

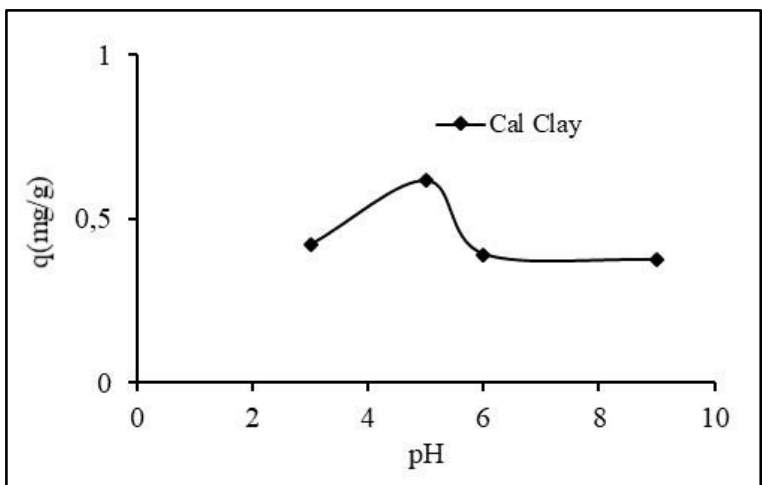

Figure 6: $\mathrm{pH}$ effect on adsorption of MO. $\mathrm{C}_{0}=20 \mathrm{mg} / \mathrm{L}, \mathrm{R}=4 \mathrm{~g} / \mathrm{L}$, Contact time $=180 \mathrm{~min}, \mathrm{RT}$

We also notice a rapid adsorption at the beginning instead in 15 minutes, then a spreading with saturation. The first phase constitutes the main part of the adsorption phenomenon because the fixation kinetics are limited by the low residual dye concentration. In the second stage, the occupation of the deep adsorption sites requires the diffusion of adsorbent within the adsorbent micropores. After this phase we observe a saturation step.

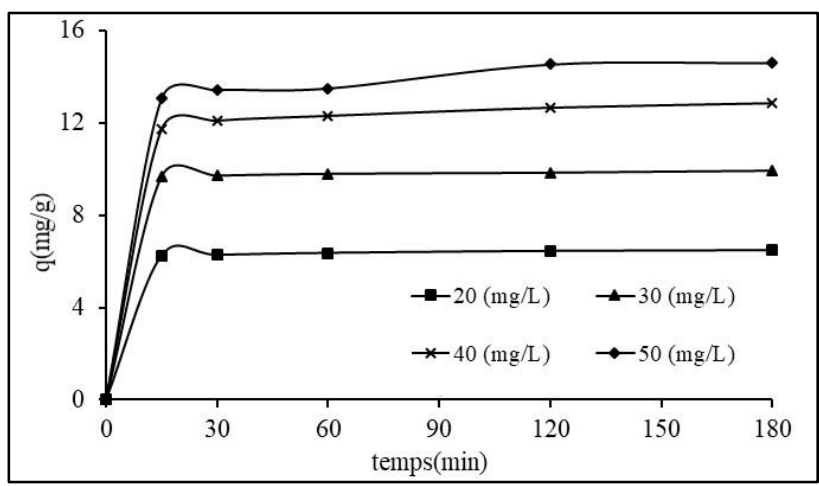

Figure 7: Change in the amount of BM adsorbed at equilibrium as a function of contact time and initial dye concentration

\subsubsection{Adsorption kinetics}

The adsorption kinetics of methylene blue and methyl orange on the crude clays were carried out at initial $\mathrm{pH}$ of the solution (8,3 for MB and 6,6 for MO) and at an initial concentration of 10 $\mathrm{mg} / \mathrm{L}$, with a clay mass of $1 \mathrm{~g} / \mathrm{L}$ for methylene blue and an initial concentration of $20 \mathrm{mg} / \mathrm{L}$, with a clay mass of $4 \mathrm{~g} / \mathrm{L}$ for methyl orange. The results are presented in figure 8 . The latter indicates that the removal of cationic dye (BM), from the solution, is very rapid. During the first 10 to 15 minutes of contact, more than $98 \%$ dye was removed. For methyl orange, the kinetics were much slower, and the percentage of elimination is $8 \%$ observed after 30 min of contact between the dye and the clay. In order to characterize the kinetics involved in the adsorption process, the 
pseudo-first-order and pseudo-second-order parameters were estimated using non-linear regression. The data obtained and the correlation coefficients, $\mathrm{r}^{2}$, are given in table 3 and figures 9 and 10.

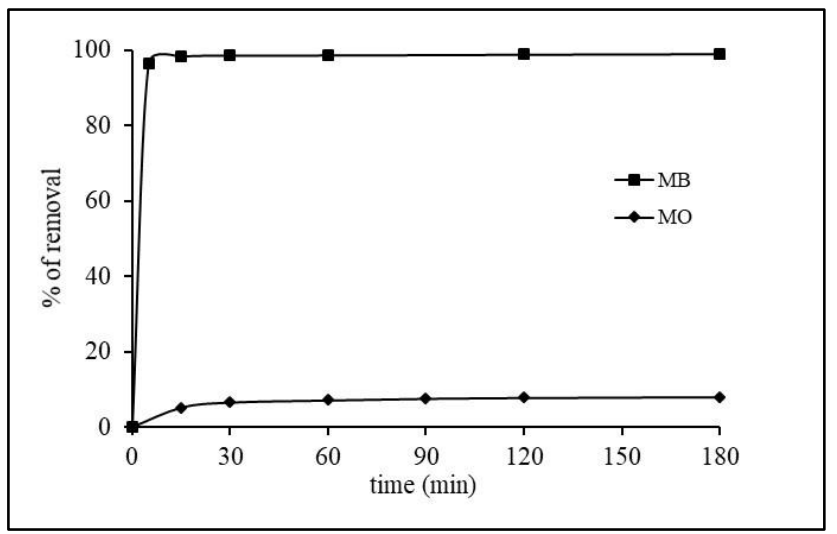

Figure 8: MB and MO adsorption kinetics

\subsubsection{Adsorption isotherms}

The adsorption isotherms were made with different initial concentrations for a ratio of $\mathrm{R}=1 \mathrm{~g} / \mathrm{L}$ for $\mathrm{MB}$, and $\mathrm{R}=4 \mathrm{~g} / \mathrm{L}$ for $\mathrm{MO}$, a contact time is 3 hours at RT and at initial $\mathrm{pH}$.

The adsorbed amounts of each dye at equilibrium $\left(\mathrm{q}_{\mathrm{e}}\right)$ as a function of the equilibrium concentration of each dye were determined in figures 11 and 12. The experimental results obtained were compared with the models of the adsorption isotherms of Langmuir and Freundlich and the constants appearing in each equation of these models were determined by nonlinear regression analysis. The constants characterising each of the systems were determined and given in table 4 .

The adsorption isotherm of methylene blue is the type $\mathrm{H}$ in the Giles classification [30]. Generally, isotherms of this type $\mathrm{H}$ are the result of the dominance of strong adsorbate-adsorbent interactions [38]. A chemical adsorption of the functional groups of the MB positively charged on the negatively charged groups on the clay surface is proposed. The experimental data for $\mathrm{MB}$ are best described by the Langmuir model. This result suggests that the adsorption process of BM on clay is a single-ply adsorption, and the maximum adsorption capacity was estimated at 15,82 $\mathrm{mg} / \mathrm{g}$. This result showed that methylene blue is uniformly adsorbed by ionic adsorption from the negatively charged surface of the clay.

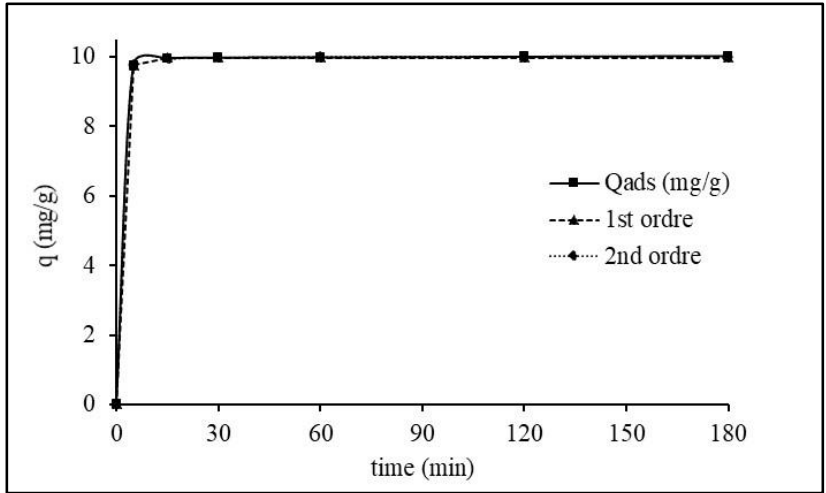

Figure 9: Adsorption kinetics, pseudo-first order and pseudo-second order of $\mathrm{MB}, \mathrm{C}_{0}=10 \mathrm{mg} / \mathrm{L}, \mathrm{R}=1 \mathrm{~g} / \mathrm{L}, \mathrm{pH}=8.3$, RT

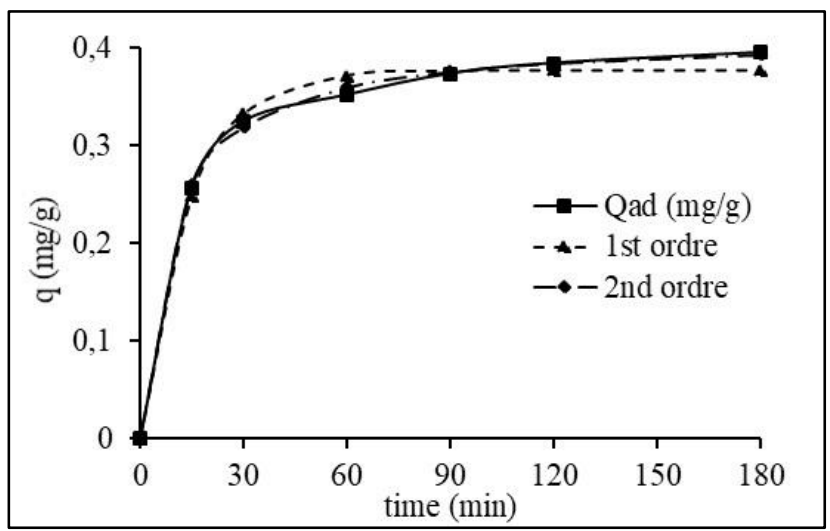

Figure 10: Adsorption kinetics, pseudo-first-order and pseudo secondorder of $\mathrm{MO}, \mathrm{C}_{0}=20 \mathrm{mg} / \mathrm{L}, \mathrm{R}=4 \mathrm{~g} / \mathrm{L}, \mathrm{pH}=6,6, \mathrm{RT}$

The adsorption isotherm of methyl orange is the type $\mathrm{S}$. The isotherms of this class correspond to an adsorption in which the adsorbate-adsorbent interactions occur, but also adsorbateadsorbate. Thus, a cooperative adsorption of molecules can be observed. Type $S$ isotherm occurs when the binding energy of the first layer is less than the binding energy between water molecules. This is due to the fact that methyl orange is an anionic molecule that has the same surface charge of clays.

Table 3: Kinetic adsorption parameters of BM and MO on raw clay

\begin{tabular}{lccccccc}
\hline \multirow{2}{*}{ Dyes } & \multicolumn{3}{c}{ pseudo-first-ordre } & \multicolumn{3}{c}{ pseudo-second-ordre } \\
\cline { 2 - 9 } & $\mathrm{q}_{\mathrm{e}(\exp )}$ & $\mathrm{q}_{\mathrm{e}}(\mathrm{mg} / \mathrm{g})$ & $\mathrm{k}_{1}(1 / \mathrm{min})$ & $\mathrm{r}^{2}$ & $\mathrm{q}_{\mathrm{e}}(\mathrm{mg} / \mathrm{g})$ & $\mathrm{k}_{2}(\mathrm{~g} / \mathrm{mg} \min )$ & $\mathrm{r}^{2}$ \\
\hline MB & 10,01597 & 9.98299 & 0.76544 & 0.99997 & 10.0147 & 0.79591 & 0.99999 \\
\hline MO & 0,395021 & 0.37727 & 0.07142 & 0.99195 & 0.41154 & 0.27514 & 0.99907 \\
\hline
\end{tabular}

Table 4: Constants for isothermal models of dye adsorption on clays

\begin{tabular}{lcccccc}
\hline \multirow{2}{*}{ Dyes } & \multicolumn{3}{c}{ Langmuir } & \multicolumn{3}{c}{ Freundlich } \\
\cline { 2 - 7 } & $\mathrm{q}_{\mathrm{m}}(\mathrm{mg} / \mathrm{g})$ & $\mathrm{K}_{\mathrm{L}}(\mathrm{L} / \mathrm{mg})$ & $\mathrm{r}^{2}$ & $\mathrm{~K}_{\mathrm{F}}\left(\mathrm{mg}^{\left.1-1 / \mathrm{n} / \mathrm{L}^{1 / \mathrm{n}} \cdot \mathrm{g}\right)}\right.$ & $\mathrm{n}$ & $\mathrm{r}^{2}$ \\
\hline BM & 15.82816 & 2.48567 & 0.9055 & 9.51471 & 0.62124 & 0.84616 \\
\hline OM & 13.7147 & 0.00243 & 0.99169 & 0.02808 & 0.97771 & 0.9936 \\
\hline
\end{tabular}


Therefore, a low adsorption affinity is observed. This suggests a physisorption provided by Van der Waals bonds. Linearity shows that the number of free sites remains constant during adsorption, this means that the sites are created during adsorption.

The adsorption of methyl orange on clays depends mainly on working conditions ( $\mathrm{pH}$, temperature, pressure, etc.). Other authors [15,39] have shown that the adsorption of methyl orange on other clays from the Safi region is greater at low temperatures and the adsorption capacity is high in acidic medium. They showed that kinetic parameters strongly influence adsorption.

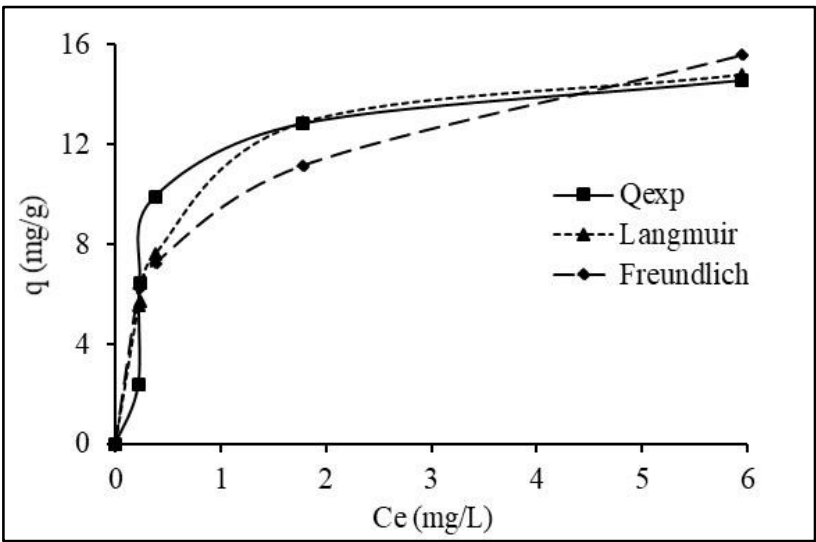

Figure 11: MB adsorption isotherms: $\mathrm{V}=200 \mathrm{~mL}, \mathrm{R}=1 \mathrm{~g} / \mathrm{L}$, $\mathrm{pH}=8,3, \mathrm{RT}$

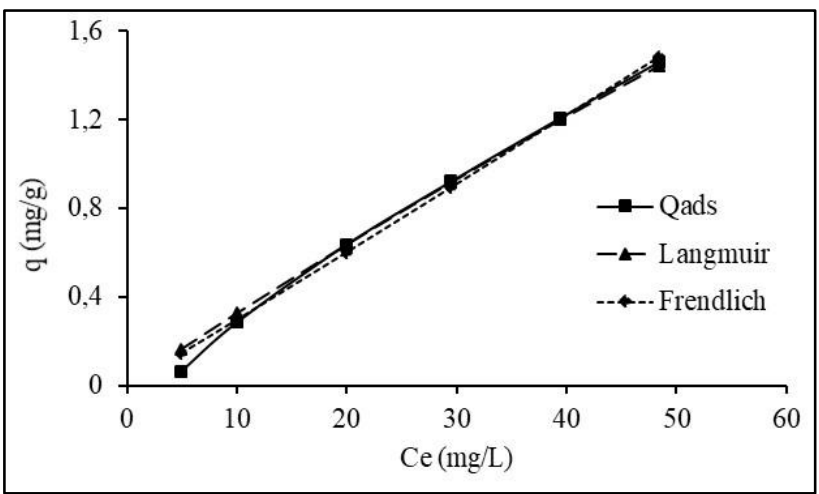

Figure 12: $\mathrm{MO}$ adsorption isotherms: $\mathrm{V}=200 \mathrm{~mL}, \mathrm{R}=4 \mathrm{~g} / \mathrm{L}$, $\mathrm{pH}=6,65, \mathrm{RT}$

\subsubsection{Effect of temperature}

The effect of temperature on the adsorption of dyes plays a very important role in the application of adsorption of various textile effluents such as organic dyes. In fact, the temperature favours the diffusion of the molecules through the outer boundary layer to the internal pores of the adsorbent particles, probably because of the decrease in the viscosity of the solution [40]. Figure 12 represents the variation of the percentage sorption of $\mathrm{MO}$ and MB on the clay as function of the temperature. The curves indicate that the temperature has no effect on the adsorption of the MB to the clay, which confirms what happened previously, that the adsorption of the MB is chemically similar, the covalent bonds are high, make their breakup very difficult. The slower decrease in the adsorption capacity of the MO with the increase in temperature is due to the measurement of the desorption step in the adsorption mechanism indicating that the process is exothermic. It is known that, the decrease in adsorption capacity with the increase in temperature is mainly due to the attenuation of adsorptive forces between the active sites on natural clay and dye molecules; anionic compound, and also between dye molecules adjacent to the adsorbed phase [41].

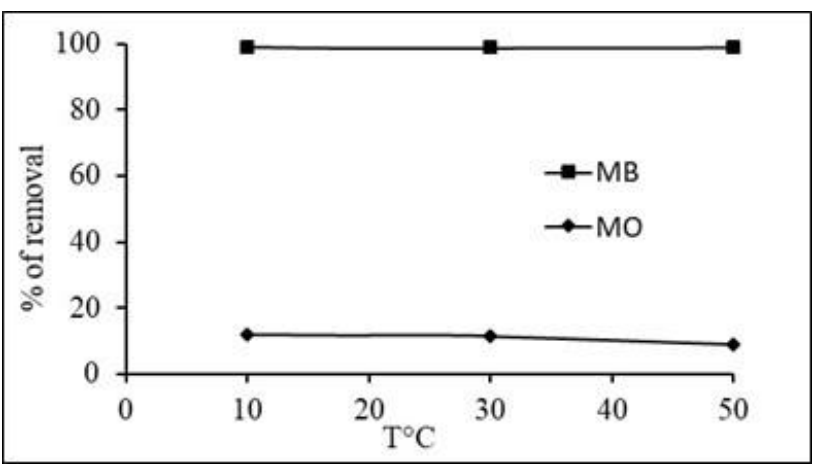

Figure 13: Effect of temperature on adsorption of MB and MO

For such equilibrium reactions, $\mathrm{K}_{\mathrm{D}}$, the distribution constant, can be expressed as:

$K_{D}=\frac{q_{e}}{C_{e}}$

Gibbs free energy is defined as:

$\Delta G^{\circ}=-R T \ln \left(K_{D}\right)$

where $R$ is the universal gas constant $(8.314$ mole $J / K)$, and $T$ is the temperature of the solution in $(\mathrm{K})$. The enthalpy $\left(\Delta \mathrm{H}^{\circ}\right)$ and the entropy $\left(\Delta \mathrm{S}^{\circ}\right)$ of adsorption were estimated from the slope and the ordinate at the origin of the curve of $\ln \left(\mathrm{K}_{\mathrm{D}}\right)$ function of $1 / \mathrm{T}$, respectively.

$\ln \left(K_{D}\right)=-\frac{\Delta G^{\circ}}{R T}=-\frac{\Delta H^{\circ}}{R T}+\frac{\Delta S^{\circ}}{R}$

The constants calculated are illustrated in Table 5. We can conclude that the adsorption process was judged to be exothermic $\left(\Delta \mathrm{H}^{\circ}\right.$ negative) in the case of the both dyes MB and MO. In the case of MO, the value of the entropy is negative this suggests a decrease in the randomness at the solid/solution interface during adsorption. Gibbs energy $\left(\Delta \mathrm{G}^{\circ}\right)$ increases as the temperature increases from 10 to $50^{\circ} \mathrm{C}$ indicating a decrease in the feasibility of adsorption at higher temperatures. In the case of $\mathrm{MB}$, the adsorption is accompanied by a decrease in the values of $\Delta \mathrm{G}^{\circ}$ with the increase in temperature. This result indicates an increase in the feasibility of adsorption at higher temperatures. The value $\Delta \mathrm{S}^{\circ}$ was found positive, which suggests an increase in the randomness at the solid / solution interface during adsorption. 
Table 5: Thermodynamic parameters calculated for the adsorption of dyes by clays

\begin{tabular}{|c|c|c|c|c|c|c|c|c|c|c|}
\hline \multirow[b]{2}{*}{$T\left({ }^{\circ} \mathrm{C}\right)$} & \multicolumn{5}{|c|}{ BM } & \multicolumn{5}{|c|}{$\mathrm{OM}$} \\
\hline & $\begin{array}{c}q_{e} \\
(\mathrm{mg} / \mathrm{g})\end{array}$ & $\mathrm{K}_{\mathrm{D}}$ & $\begin{array}{c}\Delta G^{\circ} \\
(\mathrm{KJ} / \mathrm{mol})\end{array}$ & $\begin{array}{c}\Delta H^{\circ} \\
(\mathrm{kJ} / \mathrm{mol})\end{array}$ & $\begin{array}{c}\Delta S^{\circ} \\
(\mathrm{J} / \mathrm{K} \mathrm{mol})\end{array}$ & $\begin{array}{c}q_{e} \\
(\mathrm{mg} / \mathrm{g})\end{array}$ & $\mathrm{K}_{\mathrm{D}}$ & $\begin{array}{c}\Delta G^{\circ} \\
(\mathrm{KJ} / \mathrm{mol})\end{array}$ & $\begin{array}{c}\Delta H^{\circ} \\
(\mathrm{kJ} / \mathrm{mol})\end{array}$ & $\begin{array}{c}\Delta S^{\circ} \\
(\mathrm{J} / \mathrm{K} \mathrm{mol})\end{array}$ \\
\hline 10 & 9,914 & 115,35 & $-11,177$ & & & 0,591 & 0,034 & 7,9597 & & \\
\hline 30 & 9,907 & 107,6 & $-11,791$ & $-25,61$ & 30,43 & 0,564 & 0,032 & 8,6554 & $-56,69$ & $-47,85$ \\
\hline 50 & 9,901 & 100,81 & $-12,394$ & & & 0,451 & 0,025 & 9,8974 & & \\
\hline
\end{tabular}

\section{Conclusion}

In summary, we have characterized the natural clay from the south-east of Morocco and studied its adsorption capacity in the elimination of organic pollutants from aqueous solutions. Adsorption was rapid and complete in the case of methylene blue and the pseudo-second-order model is the most suitable to describe the adsorption dynamics. The rate of adsorption can be controlled by a chemical absorption process, making this type of adsorption irreversible. The adsorption isotherm can be well described by the Langmuir equation and the optimal mass of the adsorbent evaluated is 1 gram, corresponding to a yield of $98 \%$. The increase in temperature does not affect the amount of methylene blue adsorbed. In the case of methyl orange, the adsorption reaction is slower, reaching only $8 \%$ dye removal, at different $\mathrm{pH}$ of the solution. The adsorption dynamics are described by the pseudo-second order model and the adsorption isotherm can be well described by the Freundlich equation. Increased temperature reduces the amount of dye adsorbed.

\section{Aknowledgment}

The authors would like to thank University Sultan Moulay Slimane of Beni Mellal for supporting this study.

\section{Ethical issue}

Authors are aware of, and comply with, best practice in publication ethics specifically with regard to authorship (avoidance of guest authorship), dual submission, manipulation of figures, competing interests and compliance with policies on research ethics. Authors adhere to publication requirements that submitted work is original and has not been published elsewhere in any language.

\section{Competing interests}

The authors declare that there is no conflict of interest that would prejudice the impartiality of this scientific work.

\section{Authors' contribution}

All authors of this study have a complete contribution for data collection, data analyses and manuscript writing

\section{References}

1. Bagane M, Guiza S. Removal of a dye from textile effluents by adsorption. Ann. Chim. Sci. Mat. 2000; 25: 615-625.

2. Rajumon R, Anand JC, Ealias AM, Desai DS, George G, Saravanakumar MP. Adsorption of textile dyes with ultrasonic assistance using green reduced graphene oxide: An in-depth investigation on sonochemical factors. J. Environ. Chem. Eng. 2019; 7(6): 103479.

3. Abu Hassan MA, Li TP, Noor ZZ. coagulation and flocculation treatment of wastewater in textile industry using chitosan. J. Chem. Natural Resources Engi., 2009; 4(1): 43-53.
4. Hossen MZ, Hussain ME, Al Hakim, Islam K, Uddin MN, Azad AK. Biodegradation of reactive textile dye Novacron Super Black G by free cells of newly isolated Alcaligenes faecalis AZ26 and Bacillus spp obtained from textile effluents. Heliyon 2019; 5(7): e02068.

5. Yang C, Xu W, Nan Y, Wang Y, Hu Y, Gao C, Chen X. Fabrication and characterization of a high performance polyimide ultrafiltration membrane for dye removal. J. Colloid Interf. Sci., 2020; 562(7): 589-597.

6. Basha CA, Selvakumar KV, Prabhu HJ, Sivashanmugam P, Lee $\mathrm{CW}$. Degradation studies for textile reactive dye by combined electrochemical, microbial and photocatalytic methods. Sep. Purif Technol., 2011; 79(3): 303-309.

7. Herrera-González AM, Caldera-Villalobos M, Peláez-Cid A Adsorption of textile dyes using an activated carbon and crosslinked polyvinyl phosphonic acid composite. J. Environ. Manage., 2019; 234: 237-244.

8. Mahjoubi FZ, Khalidi A, Elhalil A, Barka N. Characteristics and mechanisms of methyl orange sorption onto $\mathrm{Zn} / \mathrm{Al}$ layered double hydroxide intercalated by dodecyl sulfate anion. Sci. African 2019; 6: e00216.

9. Das I, Das S, Chakraborty I, Ghangrekar M.M. Bio-refractory pollutant removal using microbial electrochemical technologies: A short review. J. Indian Chemical Society, 2019; 96(4): 493-497.

10. Barka N, Assabbane A, Ichou Y, Nounah A. Decantamination of textile wastewater by powdered activated carbon. J. Appl. Sci. 2006; 6: 692-695.

11. Kausar A, Iqbal M, Javed A, Aftab K, Nazli Z, Bhatti HN, Nouren $\mathrm{S}$. Dyes adsorption using clay and modified clay: A review. J. Molec. Liquids 2018; 256: 395-407.

12. Gomes C, Silva JB. Minerals and Clay Minerals in Medical Geology. Appl. Clay Sci., 2007; 36: 4-21.

13. Carretero MI, Pozo M. Clay and non-clay minerals in the pharmaceutical industry: Part I. Excipients and medical applications. Appl. Clay Sci., 2009; 46: 73-80.

14. Williams L, Hillier S. Kaolins and Health: From First Grade to First Aid. Elements, 2014; 10: 207-211.

15. Elmoubarki R, Mahjoubi FZ, Tounsadi H, Moustadraf J, Abdennouri M, Zouhri A, El Albani A, Barka N. Adsorption of textile dyes on raw and decanted Moroccan clays: Kinetics, equilibrium and thermodynamics. Water Resour. Ind. 2015; 9: 1629.

16. Yariv S, Cross H. Organo-clay Complexes and Interaction, Marcel Dekker New York, 2002, viii +688 pages.

17. Das I, Das S, Dixit R, Ghangrekar M.M. Goethite supplemented natural clay ceramic as an alternative proton exchange membrane and its application in microbial fuel cell. Ionics (2020).

18. Bhowmick G.D, Das S, Ghangrekar M.M, Mitra A, Banerjee R. Improved Wastewater Treatment by Combined System of Microbial Fuel Cell with Activated Carbon/ $/ \mathrm{TiO}_{2}$ Cathode Catalyst and Membrane Bioreactor. J. Inst. Eng. India: Ser. A, 2019; 100: 675-682.

19. Bhowmick G.D, Das S, Verma H.K, Neethu B, Ghangrekar M.M Improved performance of microbial fuel cell by using conductive ink printed cathode containing $\mathrm{Co}_{3} \mathrm{O}_{4}$ or $\mathrm{Fe}_{3} \mathrm{O}_{4}$. Electrochimica Acta 2019, 310: 173-183.

20 Wang L, Zhang J, Wang A. Removal of methylene blue from aqueous solution using chitosan-g-poly(acrylic 
acid)/montmorillonite superadsorbent nanocomposite. Colloids Surf. A:Physicochem. Eng. Asp. 2008; 322: 47-53.

21. Rastogi SC, Barwick VI, Carter SV. Identification of organic colourants in cosmetics by HPLC-diode array detection. Chromatographia, 1997; 45: 215-228.

22. Zhang L, Hu P, Wang J, Liu Q, Huang R. Adsorption of methyl orange (MO) by $\mathrm{Zr}$ (IV)-immobilized cross-linked chitosan/bentonite composite. Int. J. Biol. Macromol. 2015; 81: 818-827.

23. Kou T, Wang Y, Zhang C, Sun J, Zhang Z. Adsorption behavior of methyl orange onto nanoporous core-shell $\mathrm{Cu} @ \mathrm{Cu}_{2} \mathrm{O}$ nanocomposite. Chem. Engi. J. 2013; 223: 76-83.

24. Lagergren S. About the theory of so-called adsorption of soluble substance, Kungliga Svenska Ventenskapsakademiens Handlingar 1898; 24: 1-39.

25. Ho YS, Mckay FG. kinetic models for the sorption of dye from aqueous solution by wood. Trans IChemE, Part B, 1998; 76: 183191.

26. Langmuir I. The constitution and fundamental properties of solids and liquids. Part I. Solids. J. Am. Chem. Soc. 1916; 38: 22212295.

27. Pignatello JJ. The Measurement and Interpretation of Sorption and Desorption Rates for Organic Compounds in Soil Media. Advances in Agronomy 1999; 69: 1-73.

28. Freundlich $\mathrm{H}$ and Heller W. The Adsorption of cis- and transAzobenzene. J. Am. Chem. Soc. 1939; 61: 2228-2230.

29. Tóth J. Thermodynamical Correctness of Gas/Solid Adsorption Isotherm Equations. J. Colloid and Inter. Scie. 1994; 163: 299302.

30. Giles CH, MacEwan TH, Nakhwa SN, Smith D. Studies in adsorption. Part XI. A system of classification of solution adsorption isotherms, and its use in diagnosis of adsorption mechanisms and in measurement of specific surface areas of solids. J. Chem. Soc. 1960; 846: 3973-3993.

31. Jarraya I, Fourmentin S, Benzina M. Adsorption de COV par un matériau argileux tunisien organo-modifié. J. Société Chimique de Tunisie 2010; 12: 139-149.

32. Sadki H, Ziat K, Saidi M. Adsorption d'un colorant cationique d'un milieu aqueux sur une argile locale activée (adsorption of dyes on activated local clay in aqueous solution). J. Mater. Environ. Sci. 2014; 5: 2060-2065.

33. Farmer VC. Transverse and longitudinal crystal modes associated with $\mathrm{OH}$ stretching vibrations in single crystals of kaolinite and dickite. Spectrochimica Acta Part A: Molecular and Biomolecular Spectroscopy 2000; 56: 927-930.

34. Lahsini A, Bentama J, Addaou A, Rafiq M. Caractérisation physico-chimique et étude du frittage d'une argile destinée à l'élaboration de membranes de filtration tangentielle. J. Chim.Phys. 1998;95: 1001-1019.

35. Langford H, Hodson A, Banwart S. Using FTIR spectroscopy to characterize the soil mineralogy and geochemistry of cryoconite from Aldegondabreen glacier. Appl. Geochem. 2011; 26: S206S209.

36. Ramseyer K, Miano TM, D'Orazio V, Wildberger A, Wagner T, Geister J. Nature and origin of organic matter in carbonates from speleothems, marine cements and coral skeletons. Organic Geochemistry 1997; 26 (5-6): 361-378.

37. Deniz F, Saygideger SD. Investigation of adsorption characteristics of Basic Red 46 onto gypsum: Equilibrium, kinetic and thermodynamic studies. Desalination 2010; 262: 161-165.

38. Giles CH, D'Silva AP, Easton IA. A general treatment and classification of the solute adsorption isotherm part. II. Experimental interpretation. J. Colloid Interf. Sci. 1974; 47: 766778.

39. Elmoubarki R, Moufti A, Tounsadi H, Mahjoubi FZ, Farnane M, Machrouhi A, Elhalil A, Abdennouri M, Zouhri A, Barka N. Kinetics and thermodynamics study of methylene blue adsorption onto Aleppo pine cones. J. Mater. Environ. Sci. 2016; 7: 28692879.
40. Elhalil A, Barour M, Tounsadi H, Elmoubarki R, Lemdek EM, Sadiq M, Abdennouri M, Mahjoubi FZ, Qourzal S, Barka N. Physicochemical characterization of natural sand from the southeast of Morocco and its potential use as sorbent for dyes removal. Desalin. Water Treat. 2019; 146: 362-372.

41. Panday KK, Prasad G, Singh VN. Use of wollastonite for the treatment of $\mathrm{Cu}$ (II) rich effluents. Water Air Soil Pollut. 1986; 27 287-296. 